\title{
UNDERSTANDING PAPAW AND PAPAYA CONSUMPTION IN AUSTRALIA
}

\author{
Names of Authors \\ Robin Elaine Roberts \\ Griffith Asia Institute, Griffith University \\ Nathan \\ Australia \\ Email: robin.roberts@griffith.edu.au
}

and

Catherine Burns

Department of International Business and Asian Studies, Griffith University

Nathan

Australia

Email: c.burns@griffith.edu.au

Keywords: consumer, attitudes, preferences, tropical fruit, behaviour, motivation

\begin{abstract}
Tropical fruit growers are seeking to understand the values that underlie consumers' purchasing behaviours of papaw and papaya in Australia. Accordingly, studies that identify consumer preferences for papaw and papaya are needed to aid industry success. This study took an exploratory approach to profile urban Australian papaw and papaya buyers using a sample of 819 shoppers. The purpose was to identify buyer types and socio-demographic variables influencing purchase frequency. The results revealed three buyer types: regular, occasional and irregular. Results showed that for both papaw and papaya purchasing frequency, regular and occasional buying habits decrease with age, and irregular buying habits increase with age. Overall, sensory studies are required to evaluate buyer taste preferences. Marketing communications highlighting the health and nutritional benefits of the fruit are recommended. Future research should focus on clearly understanding the buyer proposition for fresh and cut papaw and papaya.
\end{abstract}

\section{INTRODUCTION}

Papaya is an internationally recognised tropical fruit. Consumers are familiar with the retail offerings of red and yellow papaya fruit. However, in Australia the yellow fruit is known as papaw and the red as papaya. The Australian retail market for papaya presents as a dichotomy owing to this difference and yet remains under researched.

Papaya is acclaimed across a broad spectrum of natural sciences as an exceptional fruit: a 'poor man's rich food', noted in traditional medicine literature as a 'naturally gifted plant' and 'highly recommended [as a] crowning glory... which promises abundant health benefits' according to natural health researchers (Benjamin, 2012; Karunamoorthi et al., 2014; Mayo Clinic, 2015). The health and medicinal properties of papaya are widely recognised by indigenous communities where the plant is native, particularly in parts of South America, Africa, Polynesia, Southeast Asia and India. Traditional 
medicinal uses of papaya have generated scientific interest and research, particularly concerning nutritional benefits (Fanning et al., 2008; Sagnia et al., 2004). Papaya is a rich dietary source of fibre, iron, essential minerals (for example, potassium and magnesium), antioxidant nutrients (for example, carotenes and vitamin C) and the digestive enzyme, papain. A number of researchers have reported the bioavailability of carotenes in papaya is approximately three times that of carrots and tomatoes (Thokozile et al., 2001; Da Silva Oliveria et al., 2010; Evans and Ballen, 2012; Schweiggert et al, 2014).

World trade in papaya is experiencing steady growth, largely due to increasing awareness of nutritional and medicinal benefits, and greater market availability due to technological advances in combatting on-farm diseases. From 2000 to 2010, global papaya production increased by $63.7 \%$, to reach 11.2 million tonnes. World exports of fresh papaya exceeded 279,000 tonnes in 2009, with a market value of USD197 million (Evans and Ballen, 2012). Papaya is now ranked as the third most traded tropical fruit, following mangoes and pineapples. With its expanding reputation as a 'super fruit' providing health benefits, consumption of papaya is increasing in developed countries such as Japan, the United States and Canada (Otsuka, 2013; CentralAmericaData.com, 2015). Papaya imports to the United States grew by 15\% in 2014 compared to 2013. Similarly, in India and most other producing countries, awareness of papaya's nutritional and medicinal properties in conjunction with rising incomes is driving domestic demand and marketing campaigns (Thamaraikannan and Sengottuvel, 2012).

Yet preliminary marketing surveys suggest that, despite increasing interest in healthy eating, Australian consumers are largely unaware of the nutritional benefits and potential medicinal uses of papaya (Brand Story, 2008). This lack of familiarity compounded by considerable popular confusion about yellow (papaw) and red (papaya) varieties has limited the fruit's consumer appeal at a time when Australian and global markets for tropical fruit are expanding. In Australia, trade in papaya is almost entirely domestic and has remained largely static over the past decade. Between 2005 and 2011 total production was an average of 13,000 tonnes per year, with farm gate values between AUD18 million to AUD25 million (Diczbalis et al., 2012). The future, however, is buoyed by opportunities for market development. In 2012 the projected growth forecast to 2020 by Horticulture Australia was for a production volume increase to 20,000 tonnes with a farm gate value of AUD40million (GHD, 2012). Producers are aiming to expand consumer demand by replacing the traditional market for yellow flesh papaw, which currently represents $70 \%$ of total production, with the development of ten new sweeter red varieties of papaya (GHD, 2012). Research is on going to improve productivity, disease and pest resilience and to address supply chain issues post-harvest. The Australian industry is positive about the potential for domestic market growth and highlights future export industry development (Diezbalis et al., 2012).

Literature on consumer attitudes and behaviours towards purchasing papaya and papaw is scant. A preliminary study in 2008 found that a majority of Australian consumers held the misconception that papaw and papaya are different names for the same fruit (Brand Story, 2008). The yellow papaw has a longer tradition in Australia than the red papaya, extending back to the turn of the nineteenth century. In some areas of coastal Queensland and northern New South Wales the papaw has been a common domestically grown fruit. The much sweeter red papaya was introduced to the Australian market in the 1990s. Varietal confusion, coupled with a poor eating experience has 
resulted in a lack of consumer uptake of papaw and papaya in the Australian market (Nielsen, 2013).

This study aims to provide a preliminary understanding of Australian buyers and their perceptions of papaw and papaya in established east cost markets in order to develop industry-marketing strategies. This research utilises an omnibus study to identify the purchase frequency of fresh papaw and papaya during the summer of 2014 and explores the socio-demographic characteristic of buyers. The research objectives are to: 1) identify papaw and papaya buyer types; and 2) examine socio-demographic variables influencing purchase frequency of papaw and papaya.

\section{MATERIALS AND METHODS}

This exploratory research employed a CATI (computer assisted telephone interview) omnibus survey to study consumers who purchased papaw and papaya in the summer months of 2014 in Sydney and Brisbane, Australia. Interviewing was conducted on the telephone by fully trained and personally briefed interviewers. To ensure the sample included those who spent a lot time away from home, a system of call backs and appointments was adopted. The sample included 819 respondents aged 18 years and over. Socio-demographic characteristics and purchase frequencies were captured by the omnibus questions. The following question was asked of respondents, twice. Once in relation to papaw and the other for papaya:

Thinking about fresh papaw (papaya)... How often, if at all, have you purchased fresh papaw (papaya) this last year?

Would it be ...? (Read out, single response recorded)

1. More than once a week

2. Once a week

3. Once a fortnight

4. Once a month

5. Once in three months

6. Once in six months

7. or Have you not purchased at all this year

SPSS (release 20.0) software was used to examine the data with cross tabulation analysis to investigate specific socio-demographic relationships of papaw and papaya purchasing behaviours. Relationships between variables were identified using bivariate analysis of frequencies. To test the independence of the cross tabular data, the Pearson $\chi^{2}$ test was applied. In all statistical tests, a 5\% level of significance was used.

\section{RESULTS AND DISCUSSION}

\section{Socio-demographic characteristics of the buyers of papaw and papaya}

Respondents' socio-demographic characteristics, including gender, age, marital status, education and income, were examined. The gender split of respondents was $52.5 \%$ female and $47.5 \%$ male. The majority of the respondents were in the middle to older age group with $77.4 \%$ of participants being over 30 years of age. Most respondents were married or living with a partner $(60.7 \%)$, with the remaining participants in the sample being single or widowed $(29.0 \%)$, divorced or separated $(10.3 \%)$.

The highest level of education held by a majority of the respondents was a university standard degree?(31.5\%). This was followed by those who had completed technical 
and/or vocational training (36.6\%), those who completed senior high school (18.6\%), and junior high school level (13.9\%).

The majority $(34.5 \%)$ of respondents were from households earning in the lower income group of up to AU $\$ 50,000$ per household annually. The remaining respondents accounted for three groups: $30.5 \%$ of respondents in the middle level income bracket earning an annual household income above AU\$50,000 and under AU\$100,000; the highest income group (20.5\%), with annual household earnings of over AU\$100,000; and the remaining $14.5 \%$ of respondents declined to provide income details.

\section{Purchase frequency of papaw and papaya}

Different types of buyers were compared on the basis of their frequency of purchasing fresh papaw and papaya in a one-year period. The respondents were asked, 'How often if at all have you purchased papaw/papaya in the last twelve months?' Depending on their response the buyer responses were based on their purchase frequencies: regular (more than once a week or once a week); occasional (once a fortnight or once a month); irregular (once in three months or once in six months or less) and non-buyers (had not purchased this year).

The data revealed that the largest group of papaw purchasers were irregular buyers accounting $85 \%(71 \%+9 \%+5 \%)$ of the respondents. Just over $10 \%$ of respondents were occasional buyers $(7 \%+4 \%)$, and only $4 \%(3 \%+1 \%)$ of the respondents were regular buyers of papaw during the period identified.

Considering papaya buyer types, a comparable $84 \%(74 \%+7 \%+3 \%)$ of respondents were irregular buyers. Similarly, $11 \%(6 \%+5 \%)$ of respondents were occasional buyers, and $5 \%(4 \%+1 \%)$ were regular buyers of papaya during the period.

\section{Socio-demographic variables influencing purchase frequency of papaw and papaya}

Two cross-tabulations were conducted to determine if there was a significant relationship between socio-demographic variables and the purchase frequency of papaw and papaya in the given timeframe (refer Table 1 and Table 2). Validity assumptions for expected values revealed the cell counts were less than 5 in more than $20 \%$ of the comparisons indicating there may be bias in the sample for some socio-demographic comparisons. However, the results of the analyses did show that there were significant relationships between the socio-demographic variable of age and the purchase frequency of both papaya and papaw that did not violate contingency table analysis assumptions. The chi-square test statistic for age and papaya purchase frequency was $X^{2}=44.24, p<$ .001 . The chi-square test statistic for age and papaw purchasing frequency was very similar at $X^{2}=43.26, p<.001$.

The overall trend in the data for both papaw and papaya purchasing frequency is that regular and occasional buying habits decrease with age, and irregular buying habits increase with age. Whereas, in contrast, a research study conducted in 2013 found that $60 \%$ of the volume of papaw and papaya sales was attributed to senior couples, those over 60 years, with a lesser amount purchased by younger couples aged 35 to 59 years and independent singles over 35 years (Dharmaratne, 2013).

\section{Implications}

The analysis revealed that age was the only characteristic that influenced purchase frequency of papaw and papaya in the study. Gender, marital status, household income and education could not be proven to influence the purchase frequency of papaw and 
papaya. The high level of irregular papaw and papaya buyers maybe due to the time of year the study was undertaken and the sample selected. Further studies involving taste tests are recommended in order to better understand the two sets of buyers. In terms of developing future marketing strategies it is recommended that the promotion of papaw and papaya highlight the health benefits of the fruit. The introduction of new papaya varieties provides an opportunity to potentially rebrand the papaya. Through a dedicated breeding program, the creation of an improved fruit presents an opportunity to market a new super fruit.

Reflecting on the papaya survey completed by Brand Story in 2008, issues relating to aligning papaya to social awareness of healthy eating including the importance of antioxidants particularly among older consumers still require action by the industry. A number of marketing campaigns were subsequently launched to expand domestic demand using strategies such as targeted point of sale marketing, retail education, and the engagement of celebrity chefs (Dharmaratne, 2011; GHD, 2012; Dharmaratne, 2013). Generally, reviews of the marketing campaigns found that papaya consumption is influenced by food fashion and fads, particularly those generated by the media and food service industries. Overall papaya lacks saliency amongst consumers and therefore purchases tend to be unplanned and irregular. These later reports suggest that the broad awareness of papaya remains limited and although interest in healthy eating and the nutritional properties of papaya is significant, consumer understanding of the health benefits remains poor.

Based on global trends emphasising healthy eating, disease prevention and local sourcing of foods, the optimal marketing for papaya would be as a super fruit. It is well documented that papaya provides a readily available dietary source of antioxidants in the form of carotenoids including beta-carotene. Antioxidants play an important role in preventing a wide range of chronic and degenerative diseases, many associated with the aging process (Pham et al., 2008; Karunamoorthi et al., 2014). Papaya could be promoted as a natural source of beta-carotene as there is some evidence of increased health risks associated with supplements of beta-carotene (Packer et al., 1999).

The increasing consumer preference for cut fruit that appeals to desires for convenience; and, perceptions of greater food safety associated with buying local produce, offer further marketing opportunities for the industry. New technologies are emerging that extend the shelf life of cut fruit (James and Ngarmsak, 2010; Liu et al., 2011). Papaya has an advantage over other fruit in its excellent stability of nutritional properties, which are often lost in food preparation stages. From a practitioner point of view this presents an opportunity to design a research study to understand consumer acceptance of fresh cut papaw and papaya in an appropriate format ready for the consumer.

\section{CONCLUSION}

In summary, this exploratory study revealed that age tends to affect the purchase frequency of papaw and papaya buyers in Australia. The extent of the research scope was limited and identified the ongoing challenge for the industry in relation to consumer uptake of papaw and papaya in the Australian market. This complexity may be due to Australian buyers' preconceptions of papaw and papaya and lack of familiarity with the fruit. Buyers in Australia are faced with a large range of tropical fruit in the retail environment. Improvement in collaborative industry targeted papaw and papaya marketing communication programs which highlight consumer benefits would be 
beneficial. Australians find specialist fruit too expensive and forming a value-proposition will be necessary to increase the uptake and average weight of purchase in the future. The importance of understanding consumer motives and the barriers to adoption needs to be fully understood, as well as sensory evaluation between papaw and papaya. Future research should focus on clearly understanding the buyer proposition for fresh and cut papaw and papaya.

\section{Literature Cited}

Brand Story. 2008. Papaya Australia Research Debrief, Horticulture Australia.

CentralAmericaData.com. 2015. USA Consuming More Papaya. Retrieved from http://www.centralamericadata.com/en/article/home/USA_Consuming_More_Papaya.

Benjamin, R.P. 2012. Papaya ryots in Vizag district reaping it rich. The Hindu. Retrieved from http:/www.thehindu.com/todays-paper/tp-national/tp-andhrapradesh/papayaryots-in-vizag-district-reaping-it-rich/article2887519.ece

Da Silva Oliveira, D. Lemos Lobato, A., Rocha Ribeiro, S., Campos Santana, A., Chaves, J. and Pinheiro-Sant'ana, H. 2010. Carotenoids and Vitamin C during Handling and Distribution of Guava, Mango, and Papaya at Commercial Restaurants. Journal of Agriculture and Food Chemistry. 58: 6166-6172

Dharmaratne, S. 2011. Papaya Industry Situational Analysis. Horticulture Australia.

Dharmaratne, S. 2013. Report to the Advisory Committee. Horticulture Australia

Diczbalis, Y., Williams, B. and Hickery, M. 2012. Industry Situation Statement Papaya. Horticulture Industry Network. Retrieved from http://www.hin.com.au/resources/industry-situation-statement-papaya

Evans, E. and Ballen, F. 2012. An overview of global papaya production, trade, and consumption. University of Florida. IFAS Extension. Retrieved from http://edis.ifas.ufl.edu/fe913.

Fanning, K., Murray, D., Stanley, R. and Netzel, M. 2008. The health benefits of tropical fruit grown in Queensland, Australia. Conference Proceedings, Tropical fruits in human nutrition and health conference. Brisbane, Australia.

GHD 2012. Papaya Industry Strategic Investment Plan 2012/14 - 2017/18, Horticulture Australia.

James, J. and Ngarmsak, T. 2010. Processing of fresh-cut tropical fruits and vegetables: A technical guide. FAO Regional Office, Asia and the Pacific. Bangkok. Retrieved from http://www.fao.org/docrep/014/i1909e/i1909e00.htm.

Liu, D., Cusack, A., Currie, M., Pun, S., Edwards, D., and Sultanbawa, Y. 2011. Shelf Life of Fresh-Cut Papaya with Plant Extracts. Proceedings, 12th Government Food Analysts Conference, Brisbane, Australia, 22-24 Feb.

Karunamoorthi, K., Kim, H., Jegajeevanram, K., Xavier, J. and Vijayalakshmi, J. 2014. Papaya: A gifted nutraceutical plant - critical review of recent human health research. Tang Humanitas Traditional Medicine, 4:1-17.

Mayo Clinic Medical Information. 2015. Drugs and supplements. Beta-carotene. Retrieved from http://www.mayoclinic.com/health/beta-carotene/NS_patientbetacarotene

Nielsen. 2013. Papaya Brand Health Review. Nielsen Homescan data 15 June.

Otsuka, M. 2013. Japan Promotes GM Papaya to High Profile Food Service Providers. Retrieved from http://gain.fas.usda.gov/Recent\%20GAIN\%20Publications/ATO\%20Japan\%20Promo 
tes $\% 20$ GM\%20Papaya $\% 20$ to $\% 20$ High $\% 20$ Profile $\% 20$ Food $\% 20$ Service $\% 20$ Providers Tokyo\%20ATO_Japan_9-13-2013.pdf

Packer, L., Hiramatsu, M., Yoshikawa, T. 1999. Antioxidant Food Supplements in Human Health. Academic Press, California.

Pham, H., Lien A., Hua, H., and Chuong, P. 2008. Free Radicals, Antioxidants in Disease and Health. Int J Biomed Sci. 4: 89-96. PMCID: PMC3614697

Schweiggert, R., Kopec, R., Villalobos-Gutierrez, M., Högel, J., Quesada, S., Esquivel, P., Schwartz, S., and Carle, R. 2014. Carotenoids are more bioavailable from papaya than from tomato and carrot in humans: a randomised cross-over study. Br J Nutr. 111:490-498. doi:10.1017/S0007114513002596. NI

Sagnia, B., Fedeli, D., Casetti, R., Montesano, C., Falcioni, G. and Colizzi, V. 2014. Antioxidant and Anti-Inflammatory Activities of Extracts from Cassia alata, Eleusine indica, Eremomastax speciosa, Carica papaya and Polyscias fulva Medicinal Plants Collected in Cameroon. PLoS ONE. 9: e103999. Retrieved from doi:10.1371/journal.pone. 0103999

Thamaraikannan, M. and Sengottuvel, C. 2012. Papaya Cultivation and Export. Retrieved from http://www.efymag.com/admin/issuepdf/Papaya_Dec12.pdf

Thokozile N. Ncube, T., Malaba, L. and Gebre-Medhin, $\bar{M}$. 2001. Supplementing Lactating Women with Pureed Papaya and Grated Carrots Improved Vitamin A Status in a Placebo-Controlled Trial. The Journal of Nutrition 131:1497-1502. 


\section{Tables}

Table 1. Papaw purchase frequency among different socio-demographic groups in Australia.

\begin{tabular}{|c|c|c|c|c|c|c|c|c|}
\hline \multirow[b]{2}{*}{$\begin{array}{l}\text { Socio-demographic } \\
\text { characteristic }\end{array}$} & \multirow[b]{2}{*}{$N$} & \multicolumn{4}{|c|}{ Purchase frequency } & \multirow[b]{2}{*}{$\begin{array}{l}\text { Total } \\
(\%)\end{array}$} & \multirow[b]{2}{*}{$\begin{array}{c}\text { Pearson } \\
\chi^{2}\end{array}$} & \multirow[b]{2}{*}{ p-value } \\
\hline & & $\begin{array}{c}\text { Regular } \\
\text { buyer } \\
(\%)\end{array}$ & $\begin{array}{l}\text { Occasional } \\
\text { buyer } \\
(\%)\end{array}$ & $\begin{array}{c}\text { Irregular } \\
\text { buyer } \\
(\%)\end{array}$ & $\begin{array}{l}\text { Had not } \\
\text { purchased } \\
\text { this year } \\
(\%)\end{array}$ & & & \\
\hline \multicolumn{9}{|l|}{ Gender } \\
\hline Male & 389 & 4.7 & 12.1 & 13.8 & 69.4 & 100 & & \\
\hline Female & 430 & 4.0 & 9.3 & 14.4 & 72.3 & 100 & 2.93 & 0.817 \\
\hline \multicolumn{9}{|l|}{ Age group $\mathrm{z}$} \\
\hline 18 to 29 & 185 & 10.3 & 17.8 & 11.8 & 60.0 & 100 & & \\
\hline 30 to 49 & 286 & 3.8 & 8.4 & 16.0 & 71.7 & 100 & & \\
\hline 50 and over & 348 & 1.5 & 8.6 & 13.7 & 76.1 & 100 & 43.26 & $<0.001$ \\
\hline \multicolumn{9}{|l|}{ Marital status ${ }^{\mathrm{Z}}$} \\
\hline Married/De-facto & 496 & 4.3 & 10.9 & 18.0 & 66.9 & 100 & & \\
\hline Single/Widowed & 237 & 5.4 & 11.4 & 9.3 & 73.9 & 100 & & \\
\hline Divorced/Separated & 86 & 1.2 & 7.0 & 4.7 & 87.1 & 100 & 50.56 & 0.011 \\
\hline \multicolumn{9}{|l|}{ Education level attained } \\
\hline University & 258 & 8.9 & 13.2 & 17.0 & 60.9 & 100 & & \\
\hline $\begin{array}{l}\text { Technical and/or } \\
\text { vocational }\end{array}$ & 543 & 3.0 & 10.9 & 14.3 & 71.9 & 100 & & \\
\hline Senior high school & 152 & 1.3 & 9.2 & 13.8 & 75.7 & 100 & & \\
\hline Junior high school & 114 & 0.9 & 6.2 & 7.9 & 85.1 & 100 & 85.68 & $<0.001$ \\
\hline \multicolumn{9}{|c|}{$\begin{array}{l}\text { Avge. annual household } \\
\text { income (AUD) }\end{array}$} \\
\hline$<15,000$ & 37 & 2.7 & 5.4 & 18.9 & 73.0 & 100 & & \\
\hline $15,000-25,000$ & 76 & 5.2 & 5.2 & 3.9 & 85.5 & 100 & & \\
\hline $25,000-35,000$ & 68 & 1.5 & 14.7 & 5.9 & 77.9 & 100 & & \\
\hline $35,000-50,000$ & 101 & 2.0 & 6.9 & 20.8 & 70.3 & 100 & & \\
\hline $50,000-75,000$ & 131 & 5.4 & 11.4 & 14.5 & 68.7 & 100 & & \\
\hline $75,000-100,000$ & 119 & 5.0 & 13.5 & 18.5 & 63.0 & 100 & & \\
\hline $100,000-150,000$ & 115 & 5.2 & 17.4 & 11.3 & 66.1 & 100 & & \\
\hline $150,000-200,000$ & 31 & 12.9 & 6.5 & 22.6 & 58.1 & 100 & & \\
\hline$>200,000$ & 22 & 0.0 & 9.1 & 27.3 & 63.6 & 100 & & \\
\hline Declined to answer & 119 & 3.4 & 7.6 & 11.7 & 77.3 & 100 & 80.44 & 0.011 \\
\hline
\end{tabular}

Sample size $(\mathrm{n})=819$.

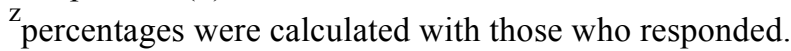


Table 2. Papaya purchase frequency among different socio-demographic groups in Australia.

\begin{tabular}{|c|c|c|c|c|c|c|c|c|}
\hline \multirow[b]{2}{*}{$\begin{array}{l}\text { Socio-demographic } \\
\text { characteristic }\end{array}$} & \multirow[b]{2}{*}{$n$} & \multicolumn{4}{|c|}{ Purchase frequency } & \multirow[b]{2}{*}{$\begin{array}{l}\text { Total } \\
(\%)\end{array}$} & \multirow[b]{2}{*}{$\begin{array}{c}\text { Pearson } \\
\chi^{2}\end{array}$} & \multirow[b]{2}{*}{ p-value } \\
\hline & & $\begin{array}{c}\text { Regular } \\
\text { buyers } \\
(\%)\end{array}$ & $\begin{array}{c}\text { Occasional } \\
\text { buyers } \\
(\%)\end{array}$ & $\begin{array}{c}\text { Irregular } \\
\text { buyers } \\
(\%)\end{array}$ & $\begin{array}{c}\text { Had not } \\
\text { purchased } \\
\text { at all this } \\
\text { year }(\%)\end{array}$ & & & \\
\hline \multicolumn{9}{|l|}{ Gender } \\
\hline Male & 389 & 6.2 & 9.5 & 11.3 & 73.0 & 100 & & \\
\hline Female & 430 & 4.5 & 11.2 & 10.2 & 74.2 & 100 & 3.48 & 0.746 \\
\hline \multicolumn{9}{|l|}{ Age group ${ }^{\mathrm{z}}$} \\
\hline 18 to 29 & 185 & 10.8 & 17.3 & 10.3 & 61.6 & 100 & & \\
\hline 30 to 49 & 286 & 5.5 & 8.7 & 11.2 & 74.5 & 100 & & \\
\hline 50 and over & 348 & 2.0 & 8.1 & 10.6 & 79.3 & 100 & 44.24 & $<0.001$ \\
\hline \multicolumn{9}{|l|}{ Marital status $\mathrm{Z}$} \\
\hline Married/De-facto & 497 & 5.5 & 10.3 & 13.5 & 70.8 & 100 & & \\
\hline Single/Widowed & 237 & 6.3 & 12.2 & 7.6 & 73.9 & 100 & & \\
\hline Divorced/Separated & 85 & 1.2 & 5.9 & 3.6 & 89.4 & 100 & 54.67 & 0.004 \\
\hline \multicolumn{9}{|c|}{ Education level attained } \\
\hline University & 258 & 10.1 & 13.2 & 15.9 & 60.9 & 100 & & \\
\hline $\begin{array}{l}\text { Technical and/or } \\
\text { vocational }\end{array}$ & 295 & 4.1 & 11.2 & 8.8 & 75.9 & 100 & & \\
\hline Senior high school & 152 & 2.7 & 10.5 & 9.2 & 77.6 & 100 & & \\
\hline Junior high school & 114 & 0.9 & 1.7 & 6.1 & 91.2 & 100 & 89.28 & $<0.001$ \\
\hline \multicolumn{9}{|c|}{$\begin{array}{l}\text { Avge. annual household } \\
\text { income (AUD) }\end{array}$} \\
\hline$<15,000$ & 37 & 5.4 & 13.5 & 8.1 & 73.0 & 100 & & \\
\hline $15,000-25,000$ & 76 & 5.2 & 5.2 & 3.9 & 85.5 & 100 & & \\
\hline $25,000-35,000$ & 68 & 4.4 & 11.8 & 5.8 & 77.9 & 100 & & \\
\hline $35,000-50,000$ & 101 & 3.0 & 8.0 & 13.9 & 75.2 & 100 & & \\
\hline $50,000-75,000$ & 131 & 3.8 & 15.3 & 11.5 & 69.5 & 100 & & \\
\hline $75,000-100,000$ & 119 & 8.4 & 12.6 & 13.5 & 65.5 & 100 & & \\
\hline $100,000-150,000$ & 115 & 8.7 & 11.3 & 11.3 & 68.7 & 100 & & \\
\hline $150,000-200,000$ & 31 & 3.2 & 9.7 & 22.6 & 64.5 & 100 & & \\
\hline$>200,000$ & 22 & 4.5 & 9.1 & 18.2 & 68.2 & 100 & & \\
\hline Declined to answer & 119 & 3.4 & 5.8 & 7.6 & 83.2 & 100 & 65.33 & 0.139 \\
\hline
\end{tabular}

Sample size $(\mathrm{n})=819$.

${ }^{z}$ percentages were calculated with those who responded. 